\title{
Observations on Scenario Based Learning (SBL) in a Medical Microbiology Teaching Lab in a Biomedical Science Course
}

\author{
Lloyd, C. ${ }^{1} \&$ Neo, P. S. ${ }^{2}$
}

\begin{abstract}
Introduction: A scenario-based learning (SBL) approach was designed for students taking the Medical Microbiology module at a tertiary educational institution. The purpose was to provide them a platform, to develop a diagnostic and research mind-set. A qualitative observational study on students' learning experiences is discussed here-in.
\end{abstract}

Methods: The SBL entitled "Save the Patient" was conducted by assigning each student-pair a hypothetical infectious disease case. In session 1, students presented their literature search on - the possible microorganisms associated with the given disease, the sample required for diagnosis and the strategies for identifying the microorganisms. In session 2, hypothetical sample duplicates comprising a microbial mix (bacteria, yeasts) was provided. Students spent three sessions isolating and identifying the microorganisms using standard techniques, with tutor guidance. The end-point was to identify the pathogens and to prescribe a correct antimicrobial to "Save the Patient." Mistakes were not penalized. Reflective qualitative observations on the various road-blocks faced and the impact on students' diagnoses were documented, to bring out areas for developing competency.

Results: Common technical and non-technical learning areas could be grouped into 9 major and 22 subcategories. Aseptic skills (68\%), streaking technique (46\%) and detailed pre-laboratory preparations $(43 \%)$ were observed by students to be key areas, where, if flawed, could result in inaccurate diagnosis.

Conclusion: The SBL learning method provided a platform for learning from mistakes in a safe environment. Students were motivated to think about their approaches and responsibly practice skills in areas they perceived as crucial, for their diagnostic career ahead.

Keywords: Teaching methods; Microbiology; Diagnosis; Scenario-based learning; Observational study

\section{Introduction}

Every medical microbiologist would agree that the daily challenge to identify pathogens from clinical samples containing myriad commensals

${ }^{1}$ Department of Health and Medical Sciences, Swinburne University of Technology, Melbourne.

${ }^{2}$ School of Life Sciences and Chemical Technology, Ngee Ann Polytechnic, Singapore.

Corresponding Author: Charmaine AC Lloyd

Swinburne University of Technology, Hawthorn, Melbourne, VIC 3122.

Email:calloyd@swin.edu.au

within a short-time, in order to render appropriate treatment for a patient with an infection, is both a skill-demanding and rewarding job. While graduate students train, it is important that the lecturer and technical officers-in-charge (LIC, TIC) simulate a work environment, to facilitate development of a diagnostic and research mindset.

In this regard, using a scenario or case-based learning (SBL) method, has been found useful when compared to the didactic approach (Singhal, 2017; Nicolaidou et al., 2019). We discuss here-in our SBL titled "Save the Patient", the learning points documented by the students and our own observations. The practical sessions were designed to resemble the work-flow experienced in clinical laboratories. We wanted our students to experience first-hand, the need for technical 
competency and to be aware how lapses could impact treatment decisions. As the teaching laboratory is a safe place to make mistakes, sticky learning experiences were allowed in order to facilitate problem-solving (Pandey, 2018).

\section{Methods}

The SBL method "Save the Patient" was used to teach second year students of the Diploma in Biomedical Sciences course at Ngee Ann Polytechnic, Singapore. All students had completed the Biosafety Passport module and year 1 General Microbiology module, which involved learning Basic Microbiology laboratory techniques.

Each student pair was assigned an infectious disease case. There were $\leq 12$ groups per class. Some examples of cases included otitis media, diarrhea, pyoderma, respiratory infections and laboratory acquired infections (LAls). Only Biosafety approved RG1 (Risk group 1) and RG2 ATCC bacteria and yeasts were used in the exercise. Pathogen safety data sheets (PSDS) were available for all microorganisms.

The SBL workflow is summarized in figure 1. In session 1, students presented their literature findings on the disease, potential pathogens and commensals associated with the sample and their proposed diagnostic methodology. Feedback and suggestions on the diagnostic design was given by the LIC. In session 2, the student pair received their challenge - tube $A$ and tube $B$ (which to them were duplicate samples from the same patient). The laboratory ICs had inoculated Tube A with 1 GNB and 1 yeast/GPC/GPB. Tube B was inoculated with an anaerobe GPB. Students were tasked to identify the pathogen and the commensal using standard methods such as culture on various available media of their choice (with aerobic, anaerobic, carbon dioxide incubation), Gram stain, motility, basic biochemical tests, API20E for GNB and antibiotic susceptibility tests. They were to report the Genus and species of the pathogen, within three sessions down-the-line, and suggest a possible antibiotic to which it was susceptible to, in order to "Save the Patient." The above technical skills may be used in diagnostic and research-based microbiology. Anaerobic culture and candle jar incubation was also incorporated to prepare students for evolving areas in gut and oral anaerobiology (Iwauchi et al., 2019).
A laboratory manual was provided to students on various protocols, media, biochemicals and interpretation of results. Report templates for each week were also provided, to help students document their results properly. Students were graded only on their presentation, technical skills, interpretation, preparedness for discussions and report writing. They were not penalized for wrong identification. They were appreciated for good reasoning and perseverance.

At the end of the sessions, reflective discussions on the areas that caused confusions in diagnosis, were discussed and grouped into learning points and categories.

\section{Results}

In this SBL, hurdles faced by students had direct impact on the subsequent stage of work. While students had received prior training in basic microbiology techniques in year 1 , the 'setting' under which they had to apply them in year 2 in the SBL was a 'challenge' to 'identify the mystery microorganisms' in a 'defined timeperiod'. Reflective learning points discussed by 37 student pairs in their reports have been categorized in table 1 . A total of 22 learning areas were identified.

\section{Discussion}

Competency in the laboratory relies heavily on knowledge, technical skills and work attitude (safety, planning, time management, proper documentation). Accurate diagnosis and antibiotic sensitivity are crucial in real-life scenarios when saving patients. SBL provides an opportunity for students to run through the whole 'diagnosis of sample' workflow. The intention is for the student to discover his/her competencies and inadequacies in technical, management and reporting skills. The three major competencies to improve upon were identified as - aseptic techniques (68\%), streaking skills $(46 \%)$ and reading and interpreting various tests (43\%). Students realized how easy it was to misdiagnose and hence provide incorrect options for treatment.

Preparations for SBL require cooperation between the ICs. Back-up support for students who are on the wrong track (e.g. no growth, misinterpretation of results) must be available. Students may face stress if they find themselves behind their class and the IC should be available to step-in. The IC must be ready to have discussions with every student group and encourage inter-group discussions. This is 
possible for those passionate about teaching Microbiology.

\begin{tabular}{l}
\hline Session* 1-Preparation: \\
Formation of Student pairs \\
Providing the case \\
Presentation of work plan \\
\hline Student group presentation comprises: \\
Research on the infectious disease case allocated \\
Possible pathogen and commensal etiolegx \\
Sample collection and processing \\
Flowchart for differentiating the etiological agents \\
\hline
\end{tabular}

\begin{tabular}{|l|}
\hline Session 2 - Tube A and Tube B provided \\
\hline Streaking \\
Tube A: 16-streak onto NA, MAC, BA, SDA (aerobic \\
incubation) - instructed by IC. \\
Other media if requested. \\
Tube B: Tryptic Soy Agar \\
(anaerobic incubation)- instructed by IC. \\
Candle jar (if requested) \\
\hline Staining - Gram stain \\
For practice and diagnosis \\
\hline Recording observations and Discussion \\
\hline
\end{tabular}

\begin{tabular}{|c|}
\hline Recording colony morphology of plates from tube $A$ and $B$ \\
\hline $\begin{array}{l}\text { Gram stain, catalase, oxidase, motility for test colonies A and B } \\
\text { from the aerobic culture }\end{array}$ \\
\hline Colony A (GNB) - Guided identification \\
\hline API20E, Biochemical tests \\
\hline Kirby Bauer test \\
\hline Colony B - Student to identify \\
\hline Tests for colony B - as per student's plans and resources \\
\hline Recording observations, Discussion \\
\hline
\end{tabular}

\begin{tabular}{|l|}
\hline $\begin{array}{l}\text { Session } 4 \text { - Report the pathogen } \\
\text { Study of the anaerobe; Troubleshooting }\end{array}$ \\
\hline $\begin{array}{l}\text { Report the pathogen and commensal and the antibiotic } \\
\text { sensitivity results }\end{array}$ \\
\hline $\begin{array}{l}\text { Colony morphology and Gram stain for the anaerobe, no further } \\
\text { action required }\end{array}$ \\
\hline Justify tests, discuss sticky situations, record learning points \\
\hline Preparation of report for submission \\
\hline
\end{tabular}

Figure 1: The SBL teaching design used to conduct the "Save the Patient" laboratory sessions *Session - weekly practical sessions (3h each)

Didactic learning (DL) is less tedious and provides a more straight-forward approach to teaching techniques. Mistakes made in one DL session have little or no impact on the next session. This may not be suitable for students who are preparing to be job-ready at graduation. While it may be argued that automation is sweeping the Microbiology laboratories (Bourbeau \& Ledeboer, 2013), decision making in selecting colonies for diagnosis cannot be replaced by machines and require knowledge and skill. 
In real research, one does not know the mix of microorganisms in unknown samples. Hence, giving students opportunities to face such challenges in the safe-setting of a teaching lab is valuable. It helps students develop skills out of their own interest and responsibility, before they step out into the industry.

\section{Table 1: Compilation of students' experiences that lead to scenario based learning in the practical sessions of "Save the Patient."}

\begin{tabular}{|c|c|c|c|c|c|}
\hline & \multicolumn{3}{|c|}{ Sequence of events that led to learning } & \multicolumn{2}{|c|}{ Aspects of learning } \\
\hline & $\begin{array}{l}\text { Sticky situations } \\
\text { faced by the students }\end{array}$ & $\begin{array}{l}\text { Impact on } \\
\text { subsequent work }\end{array}$ & $\begin{array}{l}\text { Take home } \\
\text { learning points }\end{array}$ & $\begin{array}{c}\text { Students } \\
(\%) \text { who } \\
\text { listed this } \\
\text { learning } \\
\text { point } \\
\end{array}$ & $\begin{array}{l}\text { Area of } \\
\text { learning }\end{array}$ \\
\hline 1 & $\begin{array}{l}\text { Contamination of additional } \\
\text { colonies on the primary } \\
\text { isolation plate. }\end{array}$ & $\begin{array}{l}\text { Confusion between } \\
\text { contaminants and } \\
\text { actual test } \\
\text { microorganisms } \\
\text { provided. }\end{array}$ & $\begin{array}{l}\text { Work near the heat } \\
\text { source. To avoid } \\
\text { speaking while } \\
\text { working. }\end{array}$ & 68 & Aseptic skills \\
\hline 2 & $\begin{array}{l}\text { Accidental cutting of } 1.5 \% \\
\text { agar while streaking. }\end{array}$ & $\begin{array}{l}\text { Difficult to isolate } \\
\text { colonies for } \\
\text { subsequent tests. }\end{array}$ & $\begin{array}{l}\text { To practice gentle } \\
\text { streaking. }\end{array}$ & 46 & \\
\hline 3 & $\begin{array}{l}\text { Absence of isolation in all } \\
\text { streak lines. }\end{array}$ & $\begin{array}{l}\text { No isolated colonies } \\
\text { to work with. }\end{array}$ & $\begin{array}{l}\text { Necessity to heat and } \\
\text { cool the loop while } \\
\text { streaking in different } \\
\text { directions. }\end{array}$ & 22 & Streaking skills \\
\hline 4 & Absence of colonies. & $\begin{array}{l}\text { No isolated colonies } \\
\text { to work with. }\end{array}$ & $\begin{array}{l}\text { Necessity to cool the } \\
\text { loop properly before } \\
\text { picking up a sample/ } \\
\text { streaking. Resuspend } \\
\text { the cells in the tube } \\
\text { well, before sampling. }\end{array}$ & 22 & \\
\hline 5 & $\begin{array}{l}\text { Absence of capnophiles such } \\
\text { as streptococci when included } \\
\text { in the test sample. }\end{array}$ & $\begin{array}{l}\text { Only one colony to } \\
\text { work with. }\end{array}$ & $\begin{array}{l}\text { To consider the } \\
\text { various growth } \\
\text { requirements of } \\
\text { microorganisms. To } \\
\text { remember to use a } \\
\text { candle jar. }\end{array}$ & 8 & \\
\hline 6 & $\begin{array}{l}\text { Documentation confusions } \\
\text { about results obtained from } \\
\text { colony } \mathrm{A} \text { and colony } \mathrm{B} \text {, during } \\
\text { different phases of the } \\
\text { diagnosis. }\end{array}$ & $\begin{array}{l}\text { Re-work to resolve } \\
\text { confusion before the } \\
\text { next stage. }\end{array}$ & $\begin{array}{l}\text { Proper labelling of } \\
\text { multiple colonies of } \\
\text { the two distinct } \\
\text { isolates as } A \text { and } B \text {. } \\
\text { Photographic } \\
\text { documentation for } \\
\text { beginners. }\end{array}$ & 24 & \\
\hline 7 & $\begin{array}{l}\text { Taking too much of the colony } \\
\text { left the student with less/none } \\
\text { for further diagnostic steps. }\end{array}$ & $\begin{array}{l}\text { No colony to work } \\
\text { with for subsequent } \\
\text { tests. }\end{array}$ & $\begin{array}{l}\text { Colonies of a } \\
\text { particular type should } \\
\text { be sub-cultured if } \\
\text { large concentrations } \\
\text { are required for tests. } \\
\text { To refrain from } \\
\text { exhausting the } \\
\text { colonies over a single } \\
\text { test. }\end{array}$ & 27 & Culturing skills \\
\hline 8 & $\begin{array}{l}\text { Absence of straight-forward } \\
\text { match in API20E and mixed } \\
\text { growth in Kirby Bauer disc } \\
\text { diffusion. }\end{array}$ & $\begin{array}{l}\text { Re-work due to test } \\
\text { outcome. }\end{array}$ & $\begin{array}{l}\text { To improve skills in } \\
\text { picking up isolated } \\
\text { colonies to make } \\
\text { pure colony } \\
\text { suspensions. }\end{array}$ & 19 & \\
\hline
\end{tabular}




\begin{tabular}{|c|c|c|c|c|c|}
\hline 9 & $\begin{array}{l}\text { Extremely thick or sparse } \\
\text { growth on disc diffusion tests. }\end{array}$ & $\begin{array}{l}\text { Re-work due to test } \\
\text { outcome }\end{array}$ & $\begin{array}{l}\text { Importance of Mc } \\
\text { Farland's opacity } \\
\text { tubes in adjusting } \\
\text { turbidity of broth } \\
\text { cultures. }\end{array}$ & 19 & \\
\hline 10 & $\begin{array}{l}\text { The assumption that only } \\
\text { yeasts and molds grow on } \\
\text { Saboraud's Dextrose agar } \\
\text { (SDA) led to confusion when } \\
\text { bacteria also grew }\end{array}$ & $\begin{array}{l}\text { Picking up of colonies } \\
\text { assuming they were } \\
\text { fungi, when they were } \\
\text { bacteria }\end{array}$ & $\begin{array}{l}\text { Bacteria can also } \\
\text { grow on SDA. }\end{array}$ & 8 & \multirow{4}{*}{$\begin{array}{l}\text { Reading and } \\
\text { interpreting } \\
\text { cultures and } \\
\text { tests }\end{array}$} \\
\hline 11 & $\begin{array}{l}\text { Colonies appeared much later } \\
\text { than } 24-48 \mathrm{~h} \text { under anaerobic } \\
\text { incubation }\end{array}$ & $\begin{array}{l}\text { Reporting the result } \\
\text { as negative and } \\
\text { forgetting to follow up. }\end{array}$ & $\begin{array}{l}\text { The understanding } \\
\text { that anaerobes take } \\
\text { longer to grow. }\end{array}$ & 14 & \\
\hline 12 & $\begin{array}{l}\text { API20E biochemical results } \\
\text { changed upon refrigeration }\end{array}$ & $\begin{array}{l}\text { Trouble diagnosing an } \\
\text { isolate with two } \\
\text { conflicting results } \\
\text { which would lead to } \\
\text { diagnostic errors }\end{array}$ & $\begin{array}{l}\text { To record results } \\
\text { after } 18-24 \mathrm{~h} \\
\text { incubation. }\end{array}$ & 24 & \\
\hline 13 & $\begin{array}{l}\text { Lack of preparedness to } \\
\text { interpret colony } \\
\text { characteristics and } \\
\text { biochemical results. }\end{array}$ & $\begin{array}{l}\text { Time wasted } \\
\text { researching while in } \\
\text { the lab. }\end{array}$ & $\begin{array}{l}\text { Pre-lab preparation } \\
\text { and knowledge of } \\
\text { how to interpret } \\
\text { colour changes in } \\
\text { various media used } \\
\text { in diagnosis. }\end{array}$ & 43 & \\
\hline 14 & $\begin{array}{l}\text { Thick smears with no } \\
\text { resolution between individual } \\
\text { bacteria }\end{array}$ & $\begin{array}{l}\text { Time wasted in } \\
\text { repetition }\end{array}$ & $\begin{array}{l}\text { Only a small portion } \\
\text { of the colony is } \\
\text { sufficient for a Gram } \\
\text { stain }\end{array}$ & 11 & \multirow{4}{*}{$\begin{array}{l}\text { Smear } \\
\text { preparation, } \\
\text { Gram stain, } \\
\text { Microscopy }\end{array}$} \\
\hline 15 & $\begin{array}{l}\text { Very few bacteria visible after } \\
\text { Gram stain from broth }\end{array}$ & $\begin{array}{l}\text { Time wasted in } \\
\text { repetition }\end{array}$ & $\begin{array}{l}\text { Smear from broth } \\
\text { should not be spread. }\end{array}$ & 11 & \\
\hline 16 & Confusing Gram stain results & $\begin{array}{l}\text { Time wasted in } \\
\text { repetition }\end{array}$ & $\begin{array}{l}\text { To remember the } \\
\text { order of the stains. } \\
\text { To perfect the } \\
\text { decolorization steps. }\end{array}$ & 38 & \\
\hline 17 & $\begin{array}{l}\text { Confusion between Gram } \\
\text { positive cocci and yeasts }\end{array}$ & $\begin{array}{l}\text { Correct techniques, } \\
\text { wrong diagnosis }\end{array}$ & $\begin{array}{l}\text { Must have mental } \\
\text { notes of various } \\
\text { microbial sizes }\end{array}$ & 19 & \\
\hline 18 & $\begin{array}{l}\text { Lack of preparedness to } \\
\text { identify more than a few } \\
\text { microorganisms }\end{array}$ & $\begin{array}{l}\text { Planning lapse led to } \\
\text { delays }\end{array}$ & $\begin{array}{l}\text { Importance of } \\
\text { preparing a } \\
\text { comprehensive flow- } \\
\text { chart at the time of } \\
\text { researching } \\
\text { etiological agents. }\end{array}$ & 30 & \multirow[t]{2}{*}{ Planning } \\
\hline 19 & $\begin{array}{l}\text { Assumption that only Gram } \\
\text { stain was sufficient to give the } \\
\text { diagnosis }\end{array}$ & $\begin{array}{l}\text { Last minute research } \\
\text { leading to time-waste }\end{array}$ & $\begin{array}{l}\text { Comprehensive } \\
\text { reading and } \\
\text { preparation of } \\
\text { flowcharts used in } \\
\text { diagnosis. }\end{array}$ & 8 & \\
\hline 20 & $\begin{array}{l}\text { Difficulty in distinguishing } \\
\text { positive and negative } \\
\text { biochemical tests }\end{array}$ & Errors in diagnosis & $\begin{array}{l}\text { Using positive and } \\
\text { negative controls } \\
\text { when in doubt. }\end{array}$ & 22 & Controls \\
\hline
\end{tabular}




\begin{tabular}{|c|c|c|c|c|c|}
\hline 21 & $\begin{array}{l}\text { Results improperly } \\
\text { documented during lab hours } \\
\text { were unclear at a later time }\end{array}$ & $\begin{array}{l}\text { Difficulty in compiling } \\
\text { results }\end{array}$ & $\begin{array}{l}\text { Take time to record } \\
\text { results accurately, } \\
\text { neatly and in good } \\
\text { detail. }\end{array}$ & 22 & Documentation \\
\hline 22 & $\begin{array}{l}\text { Unable to finish required work } \\
\text { for the session }\end{array}$ & Spillover of work & $\begin{array}{l}\text { Learn to plan time for } \\
\text { different experiments }\end{array}$ & 27 & $\begin{array}{l}\text { Time- } \\
\text { management }\end{array}$ \\
\hline
\end{tabular}

\section{Conclusion}

SBL is a "learning by experience" pedagogy in a simulated environment. While it is demanding on lecturers, technical staff and students, the learner-centric rewards are manifold. The goal to find the identity of the unknown microorganisms stimulates an active learning environment. Hurdles enhance the desire to master technical competencies, reflect and rethink diagnostic strategies, seek advice, improve documentation and stay resilient. Students begin to appreciate real-world diagnostic microbiologists and feel more confident about their own ability to handle the work-flow. Given the benefits to the learner, we recommend SBL in the teaching laboratory for small classes.

\section{Conflict of Interest}

The author declares no conflict of interest.

\section{References}

Bourbeau, P.P, \& Ledeboer, N.A. (2013). Automation in Clinical Microbiology. Journal of Clinical Microbiology, 51, 6, pp.1658-1665.
Iwauchi, M., Horigome, A., Ishikawa, K., Mikuni, A., Nakano, M., Xiao, J.Z., Odamaki, T. \& Hironaka, S. (2019). Relationship between oral and gut microbiota in elderly people. Immunity, inflammation and disease, 7, 3), pp. 229-236.

Nicolaidou, V., Nicolaou, P. \& Nicolaou, S.A. (2019). Transforming a cookbook undergraduate microbiology laboratory to inquiry based using a semester-long PBL case study. Advances in physiology education, 43, 1, pp. 82-92.

Pandey, A. (2018). '7 Examples on Scenario-based Learning (SBL) for formal and informal learning' - Eidesign. Available at; https://elearningindustry.com/scenario-basedlearning-sbl-formal-informal-learning-7-examples [Accessed: 12/06/2020].

Singhal, A. (2017). Case-based learning in microbiology: observations from a North West Indian Medical College. International Journal of Applied and Basic Medical Research, 7, Suppl 1, p. S47. 